\title{
AUTOMATIZÁLT ZSÁKOLÓ BERENDEZÉS
}

\section{AUTOMATED BAG PACKAGING SYSTEM}

\author{
Lőrinczi Attila $^{1}$, Egyed-Faluvégi Erzsébet ${ }^{2}$ \\ Sapientia-Erdélyi Magyar Tudományegyetem, Marosvásárhelyi Kar, \\ Gépészmérnöki Tanszék, Cím: 540485, Románia, Marosvásárhely/Koronka, 1/C \\ szám; Telefon / Fax: +40265206210/ +40265206211, \\ laagicacska@yahoo.com \\ ªluvegi.erzsebet@ms.sapientia.ro
}

\begin{abstract}
Coal produced from wood has been used in industry and the everyday life since agent times. The production, transportation and in certain cases its packaging requires hard physical labor, and it also has a negative effect on the health of workers. The present paper offers a solution to avoid these problems by the design of an automated packaging machine. This mechatronic system offers solutions to several stages of the packaging process, including: the transportation of the coal by a conveyer belt, coal selection by size, transfer of the coal to a bag by a pneumatic system and the closing of the bag by an industrial sewing machine. The proposed packaging machine has a simple, however safe design, providing flexibility to maximize its potentials in different applications.
\end{abstract}

Keywords: pneumatic cylinder, pneumatic control, bag packaging, industrial sewing machine, sifter

\section{Összefoglalás}

A fából előállított szén ősidők óta használatos úgy az iparban mint a mindennapokban. Ennek előállítása, szállítása és adott esetben csomagolása viszont kemény fizikai munkát igényel és az egészségre is ártalmas. Jelen dolgozat az előbbi problémákra és ezeknek javítására ad megoldást egy automata zsákoló berendezés formájában. Ez a mechatronikai elemekkel felszerelt berendezés több munkafolyamatot kíván megoldani, melyek a következők: a szén felhordása egy futószalag segítségével, a szétválogatása egy rostán, zsákolása pneumatikus megvalósítással és a zsák levarrása egy ipari varrógéppel. A berendezés célorientált, igazodik az adott körülményekhez, mely a lehető legegyszerübb és legbiztonságosabb kivitelt nyerte el.

Kulcsszavak: pneumatikus henger, pneumatikus vezérlés, zsákolás, ipari varrógép, rostáló

\section{Bevezetés}

A fából égetett szén az ősidők óta használatos az iparban, és a mindennapokban egyaránt. E sokrétü fütőanyag előállítása, szállítása és adott esetben csomagolása nem tartozik az egészséges, könnyü munkák körébe, mivel káros és olykor nehéz fizikai munkát igényel.

\section{A jelenleg használt technológia}

A jelenlegi berendezés felépítés szempontjából igen egyszerü, hatásos, viszont sok minőségi, és egyben veszélyes munkát igényel. Minőségit, mert a 
termelékenység a munkások sebességétől, hangulatától függ. Veszélyes, mert a szénpor belégzése a fontos szervek (tüdő, légző) károsodását okozhatja.

A napjainkban használt berendezés az 1. ábrán látható, melyet három részegységre lehet bontani.

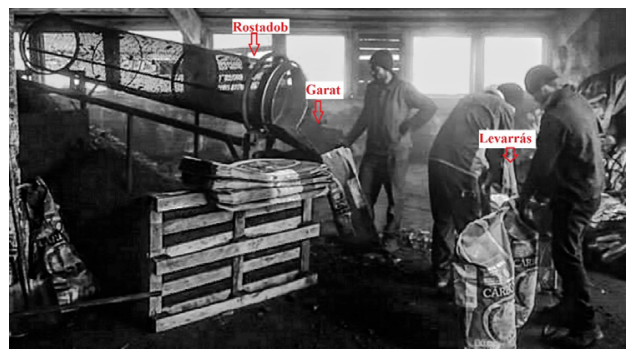

1. ábra. A jelenleg alkalmazott technológia

\subsection{Rostadob}

A rostadob általában két kör felületére kifeszített, a kívánt legkisebb szemcseméret által meghatározott, lyukazattal ellátott dobszerü kialakítás. A célfeladatnak megfelelően viszont a rostadobok készülhetnek változó lyukmérettel is.

A rostadobok feladata a szelektálás. Jelen esetben szétválasztják a $6 \mathrm{~mm}$-nél kisebb széndarabokat és a szénport az ennél nagyobb daraboktól miközben elfordulnak a saját tengelyük körül.

A rostadob szögét és fordulatszámát a szelektálni kívánt anyagtól függően határozzuk meg, empirikusan figyelve a minőség megtartását.

\subsection{Garat vagy beömlő}

A garat kialakítása igen változó, lényegében célorientált. Feladata a már kiválogatott anyagot, esetünkben szenet, eljuttatni a dob torkától a zsákba.

$\mathrm{Az}$ 1. ábrán látható beömlő méretei megegyeznek az adott zsák szájméreteivel, ezáltal a zsák könnyedén illeszthető és elkerülhetö, hogy a kiválasztott anyag a földre kerüljön.

\subsection{A zsákszáj varrógép}

A megtöltött zsákok levarrása zsákszáj varrógéppel történik, melyet a 2 . ábra szemléltet.

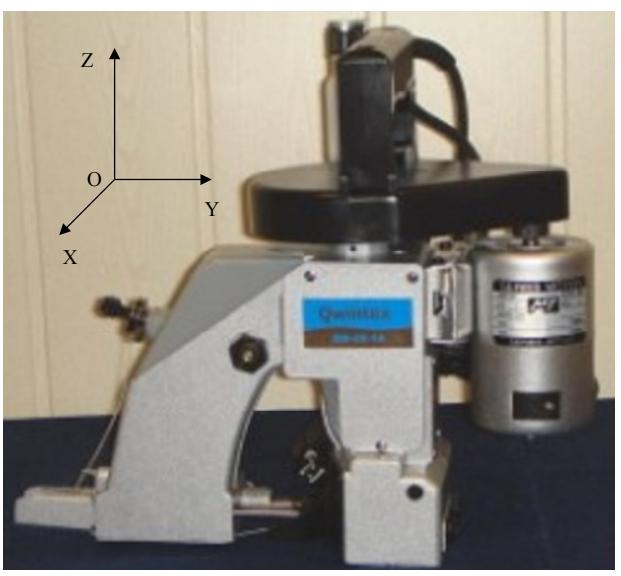

2. ábra. $A z O W$ 26-1 A ipari varrógép, [1]

Az alkalmazott varrógép egy OW 26-1 A modellü, ipari termelésre alkalmas varrógép. Ergonomikus kialakításából adódóan könnyen kezelhető, egyszerü.

A varrat egy szálas láncöltéssel, míg a szál elvágását egy $Z$ tengely körüli forgómozgással valósítjuk meg. A penge, mely elvágja a szálat, a gépbe van beépítve. Az öltések hossza 1,6-5,1 mm, és 500 öltést varr percenként. A varrógép motorjának teljesítménye $370 / 400 \quad \mathrm{~W}$, terhelésétől függően. Üzemeltetését illetően fogyasztói hálózaton müködik $230 \mathrm{~V}$ tápfeszültséggel, [1].

\section{A berendezés tervezése}

A berendezés célja a szén rostálásától a zsákba töltésén át, a zsák levarrása a bevált technológiai részletek beépítésével. A probléma felmérése és a munkafolyamat letisztulása utána a következő folyamatábrát (3. ábra) lehetett felállítani, szem előtt tartva a munkamenet folyamatosságát. 


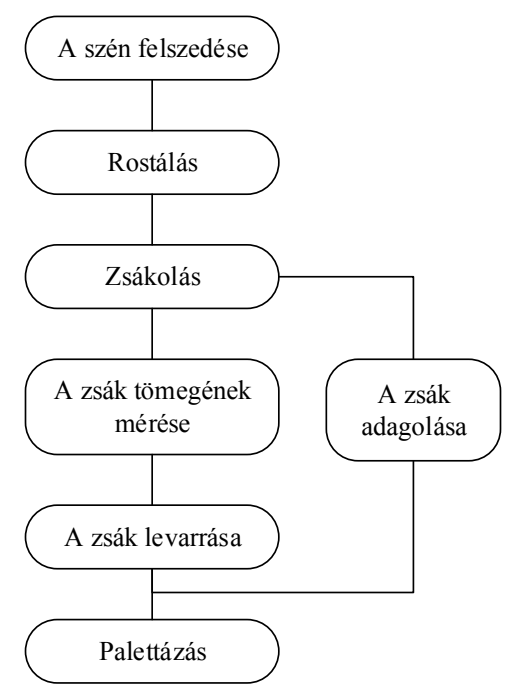

3. ábra. A berendezés folyamatábrája

Az elképzeléseink és a már létező berendezés alapján megvalósult a 4. ábrán látható 3D modell Autodesk Inventor programkörnyezetben, mely nagy segítségünkre volt kivitelezéskor.

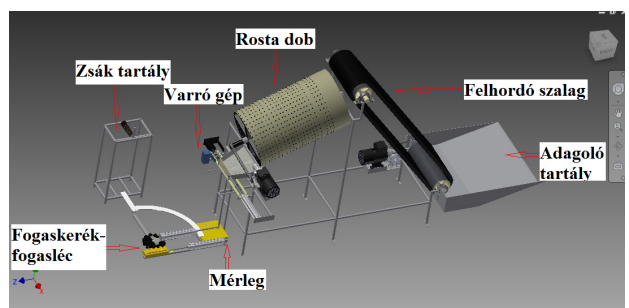

4. ábra. A berendezés Inventor modellje

A berendezés tervezésénél törekedtünk az egyszerüségre, a kivitelezhetőségre. A gép érdekessége az maga a zsák elvétele, kinyitása, megtöltése és a folyamat végén annak levarrása.

A zsák elvétele VASB-15-1/8-SI-B típusú szívókoronggal történik [2], amit tesztelés útján választottunk ki. Egy ipari kompresszor által elöállított magasnyomású levegőt egy Vn-05- H-T2 típusú vákuum generátor alakítja át, mely eljut a szívókorongokhoz. A zsákot tartó DSBC-
32-A típusú munkahenger [3] 90-os szögelfordulását egy fogaskerékfogasléckapcsolás valósítja meg.

A zsák kinyitását két-két egymással szemben elhelyezett szívókoronggal valósítjuk meg. A zsák megtöltésének folyamata a felhordódob motorjának és a rostadob motorjának egyszerre történő indításával kezdődik. A zsák kinyitott állapotban várakozik a mérlegen, a garat kapuja ekkor nyílik és a töltési folyamat mindaddig zajlik, amíg a zsák tartalmának tömege el nem éri a $3 \mathrm{~kg}$-ot. A kívánt tömeg elérése után, zár a kapu, illetve bezáródik a zsák szája is, amivel párhuzamosan a meghajtó motorok is leállnak. A garat kapujának nyitásáért, csukásáért ugyancsak egy DSBC-32-A típusú pneumatikus munkahenger a felelős. A bezárult zsák egy fogaskerék-fogasléchajtásnak köszönhetően a szája végighalad az ipari zsákvarrógép pofái közt. Mielőtt újraindulna a ciklus, mely a fent említett lépéseket követi, a tele zsákot palettázzuk.

\section{A berendezés kivitelezése}

A kivitelezett gépet az 5.ábra szemlélteti. Látható, hogy számottevő változásokat végeztünk a gép eredeti terveihez képest. A zsákot mozgató pneumatika felkerült a zsák szájának vonaláig, amire két szempontból volt szükség:

- így müködik optimálisan a rendszer;

- elhagyhatóvá váltak a modellben látható tartókarok, melyek költségcsökkentést eredményeztek.

Egy másik változtatás a varrógép elhelyezésével történt, mivel nem lett volna kivitelezhető, hogy a varrógép egy sínrendszeren fusson el a garat elött. Ez szintén egyszerüsítette a kivitelezést. Utolsó változtatást a zsáktartályon végeztük, egyszerüsítettük, hogy zökkenőmenetesen megtörténhessen a zsák elvétele és könnyebben valósuljon meg a zsák puffer 
újratöltése. A megvalósított berendezés a 6. ábrán látható.

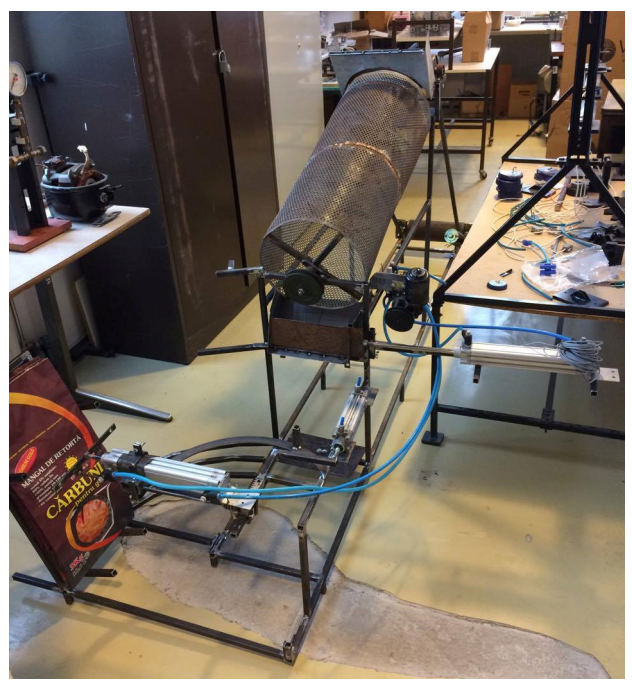

5. ábra. A megvalósitott berendezés

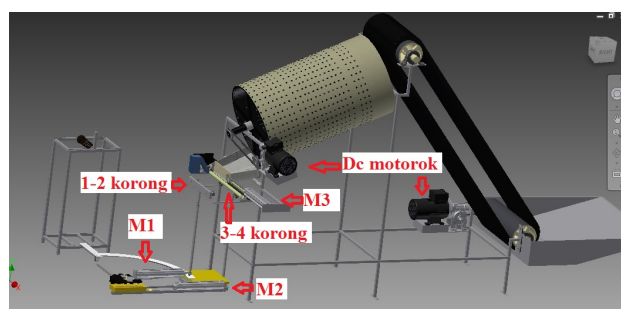

6. ábra. A berendezés vezérelt elemei

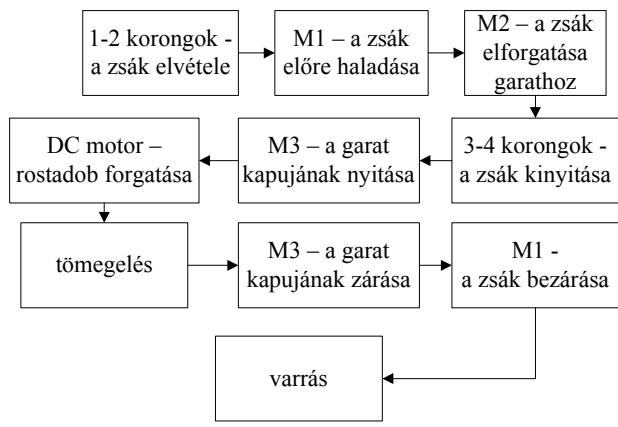

7. ábra. A berendezésben vezérelt elemek és a folyamatábra

\section{A berendezés vezérlése}

A gép mozgóalkatrészeinek vezérlését egy Arduino-val valósítjuk meg, [4]. A program megírásának első és legfontosabb lépése az, hogy meghatározzuk a logikai lépések sorrendjét. E logikai lépéseket a 7. ábra szemlélteti:

\section{Következtetések. Továbbfejlesz- tési lehetőségek}

A gép hatékonyságát növelni azzal lehetne, ha a berendezést kerekekre helyezve egy olyan vezérléssel látnánk el, mely felismerné a felzsákolásra váró szénrakást, oda menne és felszedné azt. Továbbá, a gép mellé egy palettázó robotot is lehetne kötni, mely nagyban megkönnyítené a dolgozók munkáját.

A fentieket figyelembe véve, jogosan elismerhetjük azt, hogy a mérnöki tudományt felhasználva, a probléma felismerése után, berendezésünkkel jelentősen megkönnyítettük a munkások munkakörülményeit és ezáltal a vállalat termelékenyebbé vált.

\section{Szakirodalmi hivatkozások}

[1] http://www.qwintex.hu/kezi_zsakszaj_varrog ep.html, utolsó letöltés: 2017.01.26.

[2] http://festo.partcommunity.com/3d-cadmodels, utolsó letöltés: 2017.02.13.

[3] https://www.festo.com/cat/en$\mathrm{gb} \mathrm{gb} / \mathrm{data} / \mathrm{doc}$ ENGB/PDF/EN/DSBC EN. PDF, utolsó letöltés: 2017.01.11.

[4] https://www.arduino.cc/, utolsó letöltés: 2017.01.19. 